\title{
Poliomyelitis after Poliomyelitis: Lights and Shadows of the Eradication an Introduction
}

\author{
By Juan Antonio Rodríguez-Sánchez
}

\section{Introduction}

I n October of 2013 the European Centre for Disease Prevention and Control raised the alarm about the possibility of the reintroduction of the polio virus in the European Region: Syria, a country absent poliomyelitis cases since 1995, presented new cases due to the deterioration of the health conditions during the internal armed conflicts. ${ }^{1}$ This situation brought about the reappearance of the wild poliovirus type 1 in Israel, ${ }^{2}$ which as qualified in the scientific literature as a "silent reintroduction".3

The European Region (according to the classification of the WHO) had obtained the eradication certificate for poliomyelitis in 2002, which is why the reappearance of the virus on the shores of the Mediterranean has posed serious questions and reflection about the eradication plan ${ }^{4}$ and old fears have resurfaced in

1 European Centre for Disease Prevention and Control, "Suspected outbreak of poliomyelitis in Syria: Risk of importation and spread of poliovirus in the EU", Rapid Risk Assessment. 23 October 2013. Cited 2014 Jan 17. Available from: http://www.ecdc.europa.eu/ en/publications/Publications/RRA\%20poliomyelitis\%20Syria\%2021\%2010\%202013.pdf.

2 European Centre for Disease Prevention and Control, "Expert consultation on scientific evidence linked to polio virus in Israel and Syria", Meeting Report. 5 November 2013. Cited 2014 Jan 17. Available from: http://www.ecdc.europa.eu/en/publications/Publications/ Expert\%20consultation\%20mtg\%20report\%20-\%20polio\%20Israel\%20Syria\%20-\%20final.pdf.

3 E. Kaliner, J. Moran-Gilad, I. Grotto, E. Somekh, E. Kopel, M. Gdalevich, E. Shimron, Y. Amikam, A. Leenthal, B. Lev and R. Gamzu, "Silent reintroduction of wild-type poliovirus to Israel, 2013 - Risk communication challenges in na argumentative atmosphere", Euro Surveillance, 19(7) (2014), 1-7. Cited 2014 Mar 5. Available from: http://www.eurosurveillance.org/images/dynamic/EE/V19N07/art20703.pdf

4 D. Heymann and Q. Ahmed, "The polio eradication end game: what it means for Europe", Euro Surveillance, 19(7) (2014), 1-7. Cited 2014 Mar 5. Available from: http://www.eurosurveillance.org/images/dynamic/EE/V19N07/art20702.pdf 
Occidental society towards an illness that, although it was far too easily forgotten, left a lasting impression on the central decades of the $20^{\text {th }}$ century, ${ }^{5}$

Poliomyelitis is an infection which is produced by an enterovirus, of the picornaviridae family, denoted poliovirus and having 3 different serotypes (named 1,2 and 3). Although $95 \%$ of infections proceed asymptomatically and create immunity in the individual, the remaining cases can produce an effect in the central nervous system, and even, a destruction of the motor neurons which leads to paralysis, especially of the extremities and preferentially the lower ones. This form of Poliomyelitis called paralytic, and is seen in only $0.1 \%$ of cases of infection by poliovirus and its most serious form is when it affects the respiratory, intercostals and the diaphragm musculature and causing death if patient is not put on mechanical ventilation ${ }^{6}$. It was precisely the paralytic form in children for which no immunity had been developed which gave the illness a particular significance in demolishing the dream of an invulnerable first world society, stigmatized several generations with sequaelae which changed the way people with motor disabilities were viewed and how they saw themselves, something that permitted, finally, to go beyond the medical model of disability. The cultural imprint was accompanied by iconic elements such as the iron lung which joined the orthopedic devices with which they hoped to return their gait, as well as a definitive association between vaccination and childhood.

Despite the existence of references throughout the history of humanity, ${ }^{7}$ it didn't evolve epidemically until the contemporary period and especially the $20^{\text {th }}$ century, paradoxically in the countries with the most developed Health Services and lower child mortality - known as Payne's Phenomenon - given that contact with the poliovirus was belatedly produced when the child found itself unprotected by the immunity provided by breast feeding. Between 1921 and 1955 an expansion was

5 The two major references for the general history of polio are: John R. Paul, A History of Poliomyelitis (New Haven, 1971); Mathew Smallman Raynor and Andrew D. Cliff, Poliomyelitis: Emergence to Eradication (Oxford, 2006). The most relevant focus in the history of polio has been North America, and especially the United States, where it is necessary to highlight the monographs by Naomi Rogers, Dirt and Disease: Polio before FDR (New Brunswick, 1992) and David M. Oshinsky, Polio: An American Story (New York, 2005). Other works will be cited in the next pages.

6 Jeffrey I. Cohen, "Enterovirus y reovirus", in A. Fauci et al., eds, Harrison Principios de Medicina Interna (Madrid, 2012, 17 ed.), I:1208-1213. J.F. Modin, "Poliovirus", in G.L. Mandell, J.E. Bennett and R. Dolin, Enfermedades Infecciosas. Principios y Práctica, (Madrid, 2002, 5 ed.), pp. 2305-2315. V.R. Racaniello, "One hundred years of poliovirus pathogenesis", Virology, 344 (2006), 9-16.

7 It is obligatory in any history of poliomyelitis to include the image of the Egyptian monument of Roma, priest of Astarte, which exhibits a characteristic poliomyelitis leg. Dating from the 18 dynasty, between 1403 and 1365 approximately around the reign of Amenophis III. 
witnessed, reaching its peak in the second half of the $50 \mathrm{~s}$ and beginning of the $60 \mathrm{~s}^{8}$ This tendency was reverted thanks to the appearance of 2 types of vaccine.

The injectable vaccine by Jonas Salk (which contained an inactivated virus: IPV) provided the first effective intervention in the halting of the epidemic since the great campaign carried out in the United States in 1955. 'However, to achieve a collective immunity and interrupt the transmission of the wild poliovirus, an attenuated vaccine was necessary - like that investigated by Hilary Koprowski ${ }^{10}-$ which while containing a minimum risk of producing the illness (VAPP), it also had the clear advantage of being able to transmit the immunization passively to unvaccinated people if a high enough percentage of the population was reached. In this way, fundamentally through the investigations of Albert Sabin, results were seen, at the end of the 50s, diverse oral vaccination (OPV) campaigns which owing to its form of administration, were easier to apply, more economical, produced intestinal immunity and allowed the multiplication and excretion of the vaccine virus with the effect of group immunization ${ }^{11}$.

Humans being the only reservoir for poliomyelitis meant that the appearance of this attenuated oral vaccine made the eradication of said virus possible. The global projects of the WHO had a singular aim in the Expanded Program on Immunization (EPI), started in 1974, with the objective of vaccination availability

8 \$Mathew Smallman-Raynor and Andrew D. Cliff, Poliomyelitis: Emergence to Eradication (Oxford, 2006), pp. 187-428.

9 Jonas Salk and his discovery have occupied a preferential place in scientific biographies, neighboring sometimes in the hagiography: the historic moment of the appearance of the vaccine, its interpretation in key policy (compared to vaccines such as Sabin's, linked to the sphere of socialist countries), the renounce of the rights of patent, the results obtained in the USA or, even the empty space left in the pantheon of live scientist after the death of Alexander Fleming in 1955, are some of the elements to understand how his figure has eclipsed the other investigators.

10 Hilary Koprowski and Stanley Plotkin, "History of Koprowski Vaccine Against Poliomyelitis", in Stanley A. Plotkin, ed., History of Vaccine Development (New York, 2011), pp. 155-166. Hilary Koprowski and Stanley Plotkin, "Histoire alternative du vaccin oral", in AnneMarie Moulin, dir., L'aventure de la vaccination (Paris, 1996), pp. 299-310.

11 In 1959, the First International Conference on Live Poliovirus Vaccine gave an account of 20 campaigns carried out in 15 countries. (Joseph L. Melnick, "The Picornaviruses", in F. Fenner and A. Gibbs, eds, Portraits of Viruses. A History of Virology. (Basel, 1988), pp. 147-188. Joseph Melnick and Stanley Plotkin, "Oral Polio Vaccine and the Results of Its Use", in Stanley A. Plotkin, ed., History of Vaccine Development (New York, 2011), pp. 167-177). Those implemented in some Latin American countries were reported on by Sabin himself (Albert B. Sabin, "Oral poliovirus vaccine: history of its development and use and current challenge to eliminate poliomyelitis from the world", Journal of Infectious Diseases, 151(3) (1985), 420-436. Lee Hampton, "Albert Sabin and the Coalition to Eliminate Polio from the Americas", American Journal of Public Health 99: 1 (2009), 34-44). Vaccinations as ideological instruments during the Cold War period and the role of Sabin's vaccine are analysed by Dora Vargha, "Between East and West: Polio Vaccination across the Iron Curtain in Cold War Hungary", Bulletin of the History of Medicine, 88(2) (2014), 319-343. 
in every country. The success of Smallpox eradication encouraged the implementation of even more ambitious plans: in 1982, James P Grant motivated by UNICEF "The Child Survival Revolution”, supported by GOBI (an acronym of 4 interventions in child health, hose letter "I" corresponded to" immunization") and in 1988, the $41^{\text {st }}$ World Health Assembly began the Global Polio Eradication Initiative (GPEI), a resolution with the aim of poliomyelitis eradication by the year 2000 and in answer to the private initiative set up three years earlier by Rotary International: The Polioplus Program. The magnitude of the project required the participation of various state and private bodies. Successes ${ }^{12}$ and errors of provision $^{13}$ aside, its presence continues with the goal of world health ${ }^{14}$.

Nevertheless, the particular characteristics of the poliomyelitis virus and the oral attenuated virus vaccine not only promoted the eradication but have also obligated us to reconsider some concepts: despite the elimination of the wild poliovirus in vast geographical areas, it is difficult to consider the eradication if vaccine-derived poliovirus still circulate which are capable of producing new infections and, even epidemic outbreaks. ${ }^{15}$ The advent of the artificial synthesis of polio by Wimmer, Cello and Paul, ${ }^{16}$ who reconstructed it in vitro from sequential elements of olignucleotides, incorporated a new element into the debate. Control, elimination, eradication and extinction take on nuances in which a world without the polio virus, a definite "endgame" appears difficult to envision.

\section{Chronologies of Polio: Beyond the Epidemiological Perception}

In an attempt to understand the evolution of poliomyelitis on a global scale, a variety of authors have coincided in establishing, at least, five stages: one, prior to

12 Attaining the eradication certificates in the different regions of the WHO also points to a chronology of success: 1994 (South American Region), 2000(Western Pacific Region), 2002 (European Region) and 2014(Southern Asian Region). The disappearance of wild poliovirus 2 and currently of type 3 , indicates significant advances.

13 The eradication programs were set up with fixed dates and deadlines to achieve said objectives, but have had to be systematically postponed.

14 World Health Organization, Polio Eradication \& Endgame Strategic Plan 2013-2018 (Geneva, 2013). Cited 2014 Mar 23. Available from http://www.polioeradication.org/ Portals/0/Document/Resources/StrategyWork/PEESP EN US.pdf

15 Neal Nathanson and Olen M. Kew, "From Emergence to Eradication: The Epidemiology of Poliomyelitis Deconstructed", American Journal of Epidemiology, 172 (2010), 1213-1229. Walter R. Dowdle, "The principles of disease elimination and eradication," Bulletin of the World Health Organization, 76: Suppl. 2 (1998), 22-25.

16 J. Cello, A.V. Paul, E. Wimmer, "Chemical Synthesis of Poliovirus cDNA: Generation of Infectious Virus in the Absence of Natural Template", Science, 297: 5583 (2002), 1016-1018. 
the epidemics (until 1880), followed by another period of appearance of localized epidemic outbreaks (until 1920) and a subsequent stage of increase and global expansion that ran until 1955 at the moment that Jonas Salk's vaccine permitted the dawning of a new era knows as retreat. ${ }^{17}$ For the Geographers SmallmanRaynor and Cliff, this would last until 1988, the year in which the aforementioned WHO program gave rise to a period with global eradication still inconclusive. However, for the microbiologists/virologists Nathanson and Kew other phases are distinguished: 1973 would bring to a close an emblematic stage (the eradication of the wild poliovirus in the United States), followed by a lengthy period, until the year 2000, of progress towards global eradication. A phase of challenges to the eradication arose in the years 2000 to 2010 and since the year 2000 a period characterized by problems derived from the oral vaccine has been established. ${ }^{18}$

It is an undeniable fact the usefulness of this chronology, structured by epidemiological data, which allows us to identify endemism, increase or remission and link them to specific interventions mediated by the public health policies. However, as has been demonstrated, poliomyelitis is far more than an infection, due to its cultural impact (and economic) of its paralytogenics effects in the infant population. As such, other possible approaches exist because -as written by Jan Sundin in the first issue of this magazine - the history of Public Health is an interdisciplinary field that goes beyond approximations exclusively demographic and epidemiological. ${ }^{19}$ The constructivist vision provokes us to consider elements which would allow the establishment of different chronologies as a function of the social and cultural significance of polio in the West.

The great polio epidemics, especially those of the $40 \mathrm{~s}$ to the $60 \mathrm{~s}$, mark the turning point in the social consideration of polio. Previously, before these epidemics, polio had been the source of attention for the scientific community, but -only since the epidemic outbreaks in the countries of North America and Europedid poliomyelitis become part of the social imaginary as an illness associated with childhood and motor disability, the price of prosperity and progress (the "middle class plague"), the fear of the illness and the behavior patterns characteristics of epidemics as analyzed by Rosenberg. ${ }^{20}$

17 Mathew Smallman-Raynor and Andrew D. Cliff, Poliomyelitis: Emergence to Eradication (Oxford, 2006).

18 Neal Nathanson and Olen M. Kew, "From Emergence to Eradication: The Epidemiology of Poliomyelitis Deconstructed", American Journal of Epidemiology, 172 (2010), 1213-1229.

19 Jan Sundin, "Why Hygiea Internationalis?", Hygiea Internationalis, 1(1) (1999), 5-7, p. 6.

20 Charles Rosenberg, Explaining Epidemics and Other Studies in the History of Medicine (New York, 1992), pp. 293-304. 
The appearance of the vaccines of Salk and Sabin rapidly changed this perception, and in spite of sporadic incidents (like the Cutter case), ${ }^{21}$ their convincing results restored confidence in science stuffed with triumphalism. From this moment onwards the struggle against polio is not only an objective of the Public Health system assumed by the State, but by a united public, who made it their responsibility to ensure the correct implementation of the vaccination guidelines, bearing in mind the relationship between vaccination and infancy.

The initial optimism lead many countries to set elimination deadlines for polio, internationally shared. This phase offered a major disparity between what the scientific community and the national and international bodies considered with respect to polio and what the public perceived, because polio at that time was only visible through the consequences it produced and not through the surfacing of new cases. Public Health policies were put to the test during this period, when the illness began to associate itself with poverty stricken areas, economically downtrodden or segregated for other reasons social groups, with restricted access to sanitary services and lacking in health education. In the social imaginary the significance of polio changed rapidly, and despite the marked persistent fear of the same, the illness changed its sense, taking on characteristics which associated it with "the others".

This perception was emphasized when polio was considered to be an eradicable disease and global programs were started for this end. The receipt of certificates of eradication ratified the progressive introduction of the idea that polio is an "other people" illness that belongs in far away regions of the world, a distant illness tied to poverty and non-culture; polio as a developing countries illness. Those countries are often referred to as needy recipients of international assistance (with scare questioning of the ways of the same) and habitually are perceived as threatening a reintroduction of the virus in the West. However, for society as a whole the onset of a rapid forgetfulness of poliomyelitis has grave consequences such as the appearance of anti-vaccinationist tendencies, the invisibility for people suffering the consequences of polio and the difficulties in the recognition of post-poliomyelitis syndrome and the denial of the rights of those afflicted by it.

\section{The Problems of Polio}

Poliomyelitis offers itself as an opportunity to examine the role of history in public health. ${ }^{22}$ One of the most significant examples in history and its methods as tools

21 Paul A. Offit, The Cutter Incident. How America's First Polio Vaccine Led to the Growing Vaccine Crisis (New Haven, 2005).

22 Virginia Berridge, "History in Public Health: a New Development for History?", Hygiea Internationalis, 1(1) (1999), 23-35. E. Perdiguero, J. Bernabeu, R. Huertas, E. Rodríguez- 
for public health constitutes the previously quoted work of deconstruction of the epidemiology of poliomyelitis carried out by Nathanson and Kew, ${ }^{23}$ in which the analysis of long epidemiological series and of the abundant scientific literature generated allowed them to identify the principal problems in the understanding of the infection, its epidemics and the fight against them. Starting from a chronology which clarifies the last ten years in different phases marked by the consequences of the vaccinations, the authors proposed seven questions for the understanding of polio for which they then searched for answers. Some of them allowed a connection to be formed between the articles in the present dossier and problems present in the struggle against polio.

One of the conditions which has determined the greater or lesser possibility of eradication of the polio virus has been the seasonality. Tropical climates allow for much longer periods when the transmission of the virus flourishes and in competition with other enteroviruses, at the time that the attenuated oral vaccine was at that moment more temperature sensitive than in the present. That presented major difficulties in many countries for immunization of the population only through the system of campaigns and a greater risk of the reintroduction of the virus. The persistence of wild poliomyelitis would be determined by viral epidemiology (the absence of seasonality in tropical countries, the coexistence with diarrheal diseases, high density population and bad sanitary health services, which facilitates transmission), the failure of the oral vaccine(for its own coexistence with frequent diarrhea due to the enterovirus and for the lower efficiency of the trivalent inoculation) and finally, for the material difficulty of vaccination, but also for ideological resistance.

It still hasn't been the object of an adequate historical analysis other than the problems identified by Nathanson and Kew and that which only begins to supply information in the present century. It deals with the epidemic outbreaks produced by the vaccine-derived poliovirus. Although the events in Egypt are documented since 1988, it will be the event on the island of Hispaniola (Haiti and the Dominican Republic), in 2000 and 2001, which is the first to arouse interest, while

Ocaña, "History of health, a valuable tool in public health", Journal of Epidemiology and Community Health, 55 (2001), pp. 667-673, p. 667.

23 Neal Nathanson and Olen M. Kew, "From Emergence to Eradication: The Epidemiology of Poliomyelitis Deconstructed”, American Journal of Epidemiology 172 (2010), 1213-1229. Nathanson, from Global Health Program Office, School of Medicine, University of Pennsylvania, had published, together with Martin, an article in 1979 in which they question some epidemiological characteristics of poliomyelitis (Neal Nathanson and J.R. Martin, "The epidemiology of poliomyelitis: enigmas surrounding its appearance, epidemicity, and disappearance", American Journal of Epidemiology, 110(6) (1979), 672-692). Thirty years later, they revisit those questions search for an explanation in history. 
the most serious are produced in Nigeria from $2005 .{ }^{24}$ We must realize that the cases of poliomyelitis which allowed the identification of these outbreaks were cases of poliomyelitis that proceeded with paralytic forms and it is estimated that the vaccine-associated paralytic poliomyelitis is one case in every 2.5 million administered doses, though the risk does rise by some two thousand times in situations of immunodeficiency. ${ }^{25}$ We would find ourselves therefore, with new forms of the poliovirus circulating which have recovered their virulence and infective capacity. The fact that the oral vaccine itself provides immunity from these derived-polioviruses directs the offense strategy to increase vaccination in order to achieved full coverage of the population. ${ }^{26}$ However, we now confront a new problem: the eradication of polio will not be so if we substitute the wild poliovirus for other vaccine-derived poliovirus. This leads the authors to consider the final problem, which will be the post-eradication strategy and which would have to go through a substitution of the oral vaccination for the dead virus injectable vaccine, more expensive and more complex in its administration, although all the research is currently directed towards obtaining a cheaper form, combined with other viruses and an intradermal application.

On the contrary, its epidemiological perspective leaves out of its objectives the analysis of one of the most serious problems currently in polio: its long term repercussions. Beyond the crippling immediate consequences produced by the virus, the awareness of the existence of post-polio syndrome confronts us with a reality with important public health implications, especially in societies with scare social sanitary coverage that jeopardizes the quality of life of affected people.

\section{The History of Polio, History of the Present}

From what we have seen above we can infer that the historical study of poliomyelitis is a rich model in the history of illness steeped in complexity and with a current interest for public health: we find ourselves before a recent pandemic, of grand dimensions which has become the objective for the development of a major global scale public health program to achieve its eradication, which is why historical analysis is compulsory before proposing new interventions of such a magnitude in

24 Michael B.A. Oldstone, Viruses, Plagues, and History. Past, Present, and Future (New York, 2010), pp. 159-195, p. 160. Bernard Seytre and Mary Shaffer, The death of a disease: a history of the eradication of poliomyelitis (New Brunswick, 2005), pp. 132-147.

25 Jeffrey I. Cohen, "Enterovirus y reovirus", in A. Fauci et al., eds, Harrison Principios de Medicina Interna (Madrid, 2012, 17 ed.), I:1208-1213, p. 1209.

26 José Elías García-Sánchez, Enrique García-Sánchez, Enrique García-Merino and María José Fresnadillo-Martínez, "La polio, el largo camino hacia el final de la partida", Enfermedades Infecciosas y Microbiología Clínica. In print. Cited 2015 Mar 17. Available from http://dx.doi.org/10.106/j.eimc.2014.10.005 
other diseases. In an attempt to reach this goal problems have arisen and challenges have been faced which make us pause for reflection on eradication, epidemiology and public health.

Poliomyelitis doesn't only grant us detailed historical demographic studies, but also constitutes an excellent field to study the social construction of the illness and the power relationships, the expert knowledge and the professionalism. The history of medical technology has shown itself to be especially effective when applied to poliomyelitis either in the role of vaccine, iron lung or orthopedic devices. As generating disease of motor disability is a subsidiary of fruitful approaches from disability studies, they are intimately linked to the history of the body and gender studies. ${ }^{27}$ If we join to this the peculiarity that many of who suffered from the infection are still alive, polio has invited a focused history from experience and illness narratives. ${ }^{28}$

On the whole, these implications of the history of poliomyelitis derives its framework in the history of the present. ${ }^{29}$ Without getting involved in the debates about the special historicity of the present, the definition of the temporal significance of this historical perspective or the place of memory in history and the role of witness (to quote only some controversial aspects), it is easy to understand that the researcher who deals with poliomyelitis delves into experienced history ${ }^{30}$ in which the illness, its consequences and the sufferers are current. That persistence of polio or those who live with the after-effects underline that concept of the history of the present as an analysis of ongoing processes, inconclusive history or under construction. Principally, those affected people, but including those who are connected professionally or emotionally, who, conscious of being historical subjects and having valuable memories, claim the right to question the significance of their historical action. ${ }^{31}$ The acceptance of the experience and subjectivity are intimately entwined with the transformation of the relationship between doctor and patient, with the incorporation of the expert patient knowledge. ${ }^{32}$ Post-polio syndrome is

27 José Martínez-Pérez, "Presentación: la poliomyelitis como modelo para el studio de la enfermedad en perspectiva histórica”, Asclepio, 61(1) (2009), 7-21.

28 Roy Porter, "The Patient's View: Doing Medical History from Below", Theory and Society, 14(2) (1985), 175-198.

29 Juan Antonio Rodríguez-Sánchez, "La historia de la poliomielitis, historia del presente", Temperamentum, 16 (2012). Cited 2013 Jan 30. Available from: http://www.indexf.com/temperamentum/tn16/t2712.php

30 "Historia vivida", according to Aróstegui (Magdalena González, "La teorización de Julio Aróstegui sobre la historia del tiempo presente como historia vivida", Hispania Nova, 13 (2015), 126-133.

31 Josefina Cuesta Bustillo, "La historia del tiempo presente: estado de la cuestión", Studia Historica. Historia Contemporánea, 1 (1983), 227-241.

32 Juan Antonio Rodríguez-Sánchez, "La persona enferma como experta: los cambios sociosanitarios promovidos por el asociacionismo polio-postpolio en España”, Estudos do Século $X X, 12$ (2012), 104-122. M. Siegler, "La relación médico-paciente en la era de la medicina de 
probably the most illuminating case, where the history of the present as a space of confluence between past and future acquires it sense, between memory and expectation $s^{33}$ and where the social demand for a commitment from the historian to develop critical thinking is perceived with greater clarity.

\section{The History of Poliomyelitis in Ibero-America}

In the present dossier we approach the history of poliomyelitis in a vast, diverse geographical space while having strong historical and cultural nexuses, made up of the countries of the Iberian Peninsula and by those of the Atlantic coast in South America. The presence of the illness (its incidence, significance and imaginaries), its outbreaks and the fight against it (especially the prevention through vaccination campaigns) are studied in Argentina, Uruguay and Brazil, Portugal and Spain, between 1943 and the present. In those articles how the objective of control and eradication of poliomyelitis is shaped and its relation to the global programs and the consequences of these achievements in the general population and in affected people in particular are analyzed.

On the Iberian Peninsula diverse research projects have been under development since 2005, coordinated by Rosa Ballester, on the history of polio ${ }^{34}$ and into which they have been integrating eight Spanish universities and two Portuguese ones. There poliomyelitis has been approached from diverse perspectives and historical angles in which the scientific, professional and social repercussions of the disease, contextualized with the European and international framework have been contemplated. ${ }^{35}$

gestión”, in Limitación de prestaciones sanitarias (Madrid, 1997), pp. 44-64. J. Jovell, "El paciente del siglo XXI", Anales del Sistema Sanitario de Navarra, 29: supl. 3 (2006), 85-90.

33 François Bedarida, "Definición, método y práctica de la Historia del Tiempo Presente”, Cuadernos de Historia Contemporánea, 20 (1998), 19-27. Julio Aróstegui, La historia vivida. Sobre la historia del presente (Madrid, 2004), p. 102: the present would be the history experienced by every subject and by their social collective, and it extends to their past perception and the expectation about their own future.

34 La poliomielitis en la España del siglo XX: repercusiones cientificas, profesionales y sociales. Funding Entity: MCYT. Proyectos I+D. Reference: HUM2005-073788-C03. Duración: 20052008; Enfermedades emergentes y comunidades de pacientes. Funding Entity: MICIIN. Proyectos nacionales de Promoción del Conocimiento. Plan Nacional de I+D+I.Duración. 2009-2012. Reference: HAR2009-14068-C03. El reto de la erradicación de la poliomielitis y la amenaza del sindrome post-polio: estrategias nacionales y acciones globales en la lucha contra la enfermedad y la discapacidad (1963-2010). Funding Entity: MINECO. Duración: 2013-2015.

35 The results of these projects have been published in two dossiers in renamed specialized magazines (José Martínez-Pérez, coord., "La poliomielitis y sus contextos: experiencias colectivas e individuales ante la enfermedad en el siglo XX", Asclepio, 61(1) (2009), 7-192; Rosa Ballester and María Isabel Porras, eds, "Políticas, respuestas sociales y movimientos asociativos 
In contrast, the eradication of poliomyelitis in the Americas Region in 1994 has attracted an disproportionate amount of attention from historians, with great attention paid to northern countries and much less to the rest, without this level of disinterest being justified by a lower rate of incidence. What is clear is the fact that in the United States the epidemic outbreaks were early, intense and successive for over than half a century which marked that society with a cultural imprint reaffirmed by the figure of a president, Franklin Delano Roosevelt, affected by the illness. But it is equally true that since the 30s, and fundamentally, in the 50s there existed epidemics of special virulence in the Southern Cone. Thus the studies carried out by Dilene Raimundo and the development team demonstrated, from 2002, the project "A história da poliomielite e de sua erradicação no Brasil", whose results were captured in diverse publications among them one which highlights a group effort, the first of its kind, which collected research from diverse authors about Brazil, Peru, Portugal, Spain and Pakistan. ${ }^{36}$

Another group effort arose from a round table discussion held a year later during the Congress of Spanish Society of the History of Medicine, coordinated by Adriana Alvarez, Maria Isabel Porras and Maria Jose Baguena, entitled "International perspectives of health in Latin America. Programs, methods and local experiences in the struggle against poliomyelitis (1930-1960)", during which the cases from Costa Rica, Brazil, Mexico, Cuba and Argentina were analysed. ${ }^{37}$

Precisely it is Argentina, the country which, along with Cuba and the aforementioned Brazil, has provoked the most interest in historians, especially centered on the epidemic outbreaks and the publically developed policies to fight against the infection, before and after the emergence of the vaccine, with the work of Karina Ramacciotti, the already mentioned Alvarez and Daniela Testa, who focus on the imaginaries and social response to the affected people with poliomyelitis sequelae. ${ }^{38}$ Cuba's case is of obvious interest, being the first country to

frente a la poliomielitis: la experiencia europea”, Dynamis 32(2) (2012), 273-414) and collective books (María Isabel Porras Gallo, Mariano Ayarzagüena Sanz, Jaime de las Heras Salord y María José Báguena Cervellera, coords., El drama de la polio: un problema social y familiar en la España franquista (Madrid, 2013).

36 Dilene Raimundo de Nascimento, org., A história da poliomielite (Rio de Janeiro, 2010).

37 Adriana Álvarez, María Isabel Porras Gallo and María José Báguena, coords., "Perspectivas internacionales de la salud en la América Latina. Programas métodos y experiencias locales en la lucha contra la poliomielitis (1930-1960)", in María Isabel Porras et al., eds, Transmisión del conocimiento médico e internacionalización de las prácticas sanitarias: una reflexión histórica (Ciudad Real, 2011), pp. 233-261.

38 Karina Inés Ramacciotti, "Las sombras de la política sanitaria durante el peronismo: los brotes epidémicos en Buenos Aires", Asclepio, 58(2) (2006), 115-138. Adriana Álvarez, "Parálisis y acción': el caso argentino frente a los brotes de poliomielitis de mediados del siglo XX", in María Isabel Porras et al., eds, Transmisión del conocimiento médico e internacionalización de las prácticas sanitarias: una reflexión histórica (Ciudad Real, 2011), pp. 259-261. Daniela Testa, "Poliomielitis: la 'herencia maldita' y la esperanza de la rehabilitación. La epidemia de 1956 en la ciudad de 
apply mass campaigns of the oral vaccine in 1962 and in so doing eradicated polio that same year. ${ }^{39}$ Once again epidemiology and vaccination are the focal point of interest.

In spite of Chile, ${ }^{40}$ Peru, ${ }^{41}$ Costa Rica ${ }^{42}$ and Mexico ${ }^{43}$ also having something to say in the history of polio, its battle and its eradication, the lack of attention which a large part of the Americas region receives remains puzzling, despite pioneering the eradication of the disease. The encyclopedic work of Kohn makes reference to not a single epidemic outbreak in Ibero-America (for Spain or Portugal either), ${ }^{44}$ the Cambridge World History of Human Disease hardly dedicates a paragraph to the mention of vaccination programs in Argentina, Brazil, Chile, Costa Rica, Cuba, Nicaragua and Paraguay ${ }^{45}$ and even the great and voluminous work of SmallmanRaynor and Cliff muster only twelve pages of information about vaccination in Latin America and the Caribbean, although it does include some references to epidemic outbreaks on previous pages. ${ }^{46}$ Perhaps the only point of attention,

Buenos Aires", Instersticios, 5(2) (2011), 309-323; Daniela Testa, "La lucha contra la poliomielitis: una alianza médico-social, Buenos Aires, 1943”, Salud Colectiva, 8(3) (2012), 299-314; Daniela Testa, "Curing by doing: la poliomielitis y el surgimiento de la terapia ocupacional en Argentina, 1956-1959”, História, Ciências, Saúde - Manguinhos, 20(4) (2013), 1571-1584; Daniela Testa, "El síndrome pos-polio y sus anudamientos en el pasado", Instersticios, 8(1) (2014), 233-248.

39 However, the works of Más Lago and Enrique Beldarraín speak of subsequent cases of unvaccinated children, the suspicion of interruption of wild poliovirus circulation in 1967 and its confirmation from 1970. P. Más Lago, "Eradication of poliomyelitis in Cuba: a historical perspective", Bulletin of the World Health Organization, 77(8) (1999), 681-687. Enrique Beldarraín, "Poliomyelitis and Its Elimination In Cuba: An Historical Overview", MEDICC Review, 15(2) (2013), 30-36. Cited 2014 Jan 23- Available from http://www.medicc.org/ mediccreview/index.php? issue $=24 \& \mathrm{id}=302 \& \mathrm{a}=\mathrm{va}$

40 Enrique Laval, "Anotaciones para la historia de la poliomielitis en Chile", Revista Chilena de Infectología 24(3) (2007), 247-250.

41 Deepak Sobti, Marcos Cueto and Y. He, "A public health achievement under adversity: the eradication of poliomyelitis from Peru, 1991", American Journal of Public Health, 2014, 104(12), 2298-2305.

42 Ana Paulina Malavassi Aguilar, "Representaciones sobre la epidemia de poliomielitis en el periódico La Nación. Costa Rica, 1954", in María Isabel Porras et al., eds, Transmisión del conocimiento médico e internacionalización de las prácticas sanitarias: una reflexión histórica (Ciudad Real, 2011), pp. 237-239.

43 Ana María Carrillo, "Vacunación y educación higiénica en la campaña contra la poliomielitis en México", in María Isabel Porras et al., eds, Transmisión del conocimiento médico e internacionalización de las prácticas sanitarias: una reflexión histórica (Ciudad Real, 2011), pp. 247-251.

44 George C. Kohn, Encyclopedia of Plague and Pestilence: From Ancient Times to the Present (New York, 1995).

45 Kenneth F. Kiple, ed., The Cambridge World History of Human Disease Past and Present (Cambridge, 1993), p. 949. Kenneth F. Kiple, ed., The Cambridge Historical Dictionary of Disease (Cambridge, 2003).

46 Mathew Smallman-Raynor and Andrew D. Cliff, Poliomyelitis: Emergence to Eradication (Oxford, 2006), pp. 511-523. 
embedded in triumphalist rhetoric, has been the frequent inclusion of the photographs of Peruvian child Luis Fermin Tenorio as the last affected soul in the Americas Region. The necessity for new studies are therefore confirmed, and above all, publications that halt the concealment of the sanitary situation in non-English speaking countries. ${ }^{47}$

\section{Polio: Towards a Comparative History of the Present Time}

The history of the present was given incentive by the resurgence, from the 70s of the last century, of a new political history in which reflection on power, beyond that of the institutionalized, was bound with society and culture. The history of poliomyelitis and, more concretely, of the international projects to combat it is an appropriate theme for approximations in which the tensions produced between the international sanitary organizations and their policies and the application of the same on a national level are explored. This dialogue between local and international levels is also produced in the universalization of scientific knowledge. In his study of poliomyelitis in the Argentinian province of Cordoba, Adrián Carbonetti analysis in this dossier the role of local social factors in the autochthonous production of expert knowledge. The acceptance of foreign knowledge on poliomyelitis (that is to say from North American and European science) is not static, producing a fresh signification of this and the creation of their own research strategies.

However, the most emphasized characteristic of the sanitary policies with regards to poliomyelitis was the adoption of international commitments in the fight against the same one that they led, in 1988, the ambitious global eradication (the Global Polio Eradication Initiative), which Ballester, Porras and Baguena analyse in their article on the Spanish case in its European context. Various talking points are produced on international bodies which affect the strategies to combat poliomyelitis: the WHO's own composition meant that up to the 60s global eradication projects were not established (smallpox being the first, successful and, as such, encouraging), a composition that was also influential in the commitment by the Primary Healthcare signed in Alma-Ata in 1978 and partially failed, with inevitable consequences in the form of vaccination and the organization of

47 Three differents research networks are focused on History of diseases (which include polio): Red de Estudios Histórico-Comparativos de la Medicina y la Salud Pública Latinoamericanas, Red de Viejas y Nuevas Enfermedades de la Asociación Latino-Americana de Población y la Red Iberoamericana de Investigación en Historia de la Poliomielitis y el Síndrome Post-Polio. 
epidemiological security. ${ }^{48}$ One final point to consider is one which arises from the WHO crisis in the $80 \mathrm{~s}$ and drives a progressive increase in nongovernmental funding, a very significant fact in the participation of different organizations in the eradication of polio (National Governments in coordination with the four spearheading partners -WHO, UNICEF, Rotary International and the Centers for Disease Control and Prevention- to which others can be added, such as the World Bank or the Bill \& Melinda Gates Foundation) or in the Global Alliance for Vaccines and Immunization (GAVI). ${ }^{49}$ In our case the role conducted by the Pan American Health Association (PAHO) acquires a special interest, as much in the heart of the $\mathrm{WHO}$ as in its work for the eradication of polio in the Americas Region (even facing its criteria to those of the international bodies), the first to achieve the certificate in $1994 .{ }^{50}$ This contextualization of the Spanish case with the European and Global strategies allow a reflection on the necessity to go beyond of the collective studies to carry out comparative studies which permit the analysis of the role of local determining factors and the acceptance and application of global strategies, their adaptation and results obtained. Although the national studies can illustrate many of these aspects, it is the comparative perspective which detects critical elements for the research. The well-known article by Lindner and Blume about the development of vaccines (IPV and OPV) and the adoption of one kind or another in the United Kingdom (England and Wales), the Netherlands and West Germany, shows three different processes of introduction and use. Their analysis of the intensity of the epidemic, organization of the health services and its financing, the production (state or private) of the vaccine and the activities (scientific and political) towards it, international relations, and above all, the existence of prior national developments with respect to the illness and the vaccination are some of the elements which authors claim enrich the comparative studies. $^{51}$

48 Marcos Cueto, "Los orígenes de la Atención Primaria de Salud y la Atención Primaria Selectiva de Salud", in Marcos Cueto and Víctor Zamora, eds, Historia, Salud y Globalización (Lima, 2006), pp. 27-58.

49 Theodore M. Brown, Marcos Cueto and Elizabeth Fee, "The World Health Organization and the Transition From 'International' to 'Global' Public Health", American Journal of Public Health, 96(1) (2006), 62-72.

50 Miguel Armando Mosquera Gordillo, Natalia Barón Cano and Rosa Ballester Añón, "El camino hacia la erradicación de la poliomielitis a través de la Organización Panamericana de la Salud", Revista Panamericana de Salud Pública, 36(3) (2014), 185-192. Lee Hampton, "Albert Sabin and the Coalition to Eliminate Polio from the Americas", American Journal of Public Health, 99(1) (2009), 34-44. Marcos Cueto, El valor de la salud. Una historia de la OPS (Washington, 2004).

51 Ulrike Lindner and Stuart S. Blume, "Vaccine Innovation and Adoption: Polio Vaccines in the UK, the Netherlands and West Germany, 1955-1965", Medical History, 50 (2006), 425-446. 
For the comparative polio study in Ibero-America, despite the study being pioneered for Brazil and Peru, aforementioned, ${ }^{52}$ and others for the Iberian Peninsula, ${ }^{53}$ a specific proposal still doesn't exist, although there exists a framework with a solid scientific foundation and meticulously organized by an ample international team, coordinated by Emilio Quevedo, for the comparative study of public health, health professions and their relationship with society, ${ }^{54}$ Adriana Alvarez was appointed to this project, and in his article about poliomyelitis in Argentina and Uruguay, highlights the complexity of comparative studies between countries which show marked differences themselves internally according to geographical areas. Through the analysis of health policies, vaccination programs and epidemiological data, we can compare the evolution of the illness in both countries during the governments of Peron and Batlle and their great epidemic strategies to combat the outbreaks of the mid 50s.

Furthermore, from the comparative perspective the representation of poliomyelitis and post-polio syndrome are tackled in the Spanish-Portuguese press by Guerra and Rodriguez -Sanchez. If contemporary history has always counted on the press as a relevant source, then the history of the present finds facts about the influence in its public and political agendas, with the effect of a configuration of identities. Post-polio Syndrome, dealt with by the comparative study, exemplifies the vicious circles established: the absence of collectives and social movements for polio-affected people leads to their invisibility in the Portuguese press and this disappearance causes a spread of misinformation across public society (and worse still, of the people affected) about the existence of the syndrome. To this must be

52 Dilene Raimundo do Nascimento, Marcos Cueto, Eduardo Ponce Maranhão and Deepak Sobti, "A erradicação da poliomielite na América Latina: comparando Brasil e Peru", in Dilene Raimundo de Nascimento, org., A história da poliomielite (Rio de Janeiro, 2010), pp. 161-176.

53 Sandrine Martins Pinto, Inês Guerra, Juan Antonio Rodríguez-Sánchez, João Rui Pita y Ana Leonor Pereira, "De las campañas de vacunación al calendario vacunal: el Programa Nacional de Vacinação portugués y las Campañas Nacionales de Vacunación Antipoliomielítica en España (1963-1976)", in Ricardo Campos Marín, Ángel González de Pablo, María Isabel Porras Gallo y Luis Montiel, eds, Medicina y poder político (Madrid, 2014), pp. 203-209. Juan Antonio Rodríguez-Sánchez, Rosa Ballester Añón and Inês Guerra Santos, "El movimento associativo: uma perspectiva internacional, nacional y de los casos de Madrid, Valencia y Castilla - La Mancha”, in María Isabel Porras Gallo, Mariano Ayarzagüena Sanz, Jaime de las Heras Salord y María José Báguena Cervellera, coords., El drama de la polio: un problema social y familiar en la España franquista (Madrid, 2013), pp. 233-257. João Rui Pita and Juan Antonio RodríguezSánchez, "Actitudes ante la polio en España y Portugal: estudio comparativo", in Teresa Ortiz et al., eds, La experiencia de enfermar en perspectiva histórica (Granada, 2008), pp. 331-334.

54 Emilio Quevedo, Mario Hernández, Claudia Cortés and Juan Carlos Eslava, "Un modelo para armar: Una propuesta metodológica para abordar el estudio comparativo de la historia de la salud pública, de las profesiones de la salud y de sus relaciones de doble vía con la sociedad", Revista de Ciencias de la Salud, 11(3) (2013), 295-321. 
added its effect in relation to social movements and in relation to the creation and reconstruction of identities.

\section{Memory, Testimony and History of Polio in Light of Post-Polio Syndrome}

In fact, a characteristic of the history of the present is the coexistence of territories which are troublesome to demarcate: history, investigative journalism and memory narratives ${ }^{55}$. Poliomyelitis has not only been common to its focus, but it has illustrated them prolifically. The vaccines, their trials and the incidents during their application has given rise to controversies that have elicited approaches from investigative journalism which have exalted the figure of Jonas Salk ${ }^{56}$ or has related Koprowski's trials with the origin of HIV, ${ }^{57}$ linked diverse cancers with the contamination of the vaccines by the SV $40,{ }^{58}$ or even in the poliomyelitis outbreaks from the vaccine-derived polioviruses. ${ }^{59}$ In such cases, history and journalism can, when the approximations are rigorous, be very close to the mark: share multiple sources, respond to social demand, and contrast documents and testimonies in search of their veracity. ${ }^{60}$

However, an extant illness, whose survivors have been scarred by paralytic effects, invite us to convert their memory into one of the pillars of history. The autobiographical narratives have frequently interlaced in an effort to recover a collective memory like in the cases of Black ${ }^{61}$ and Shell, ${ }^{62}$ which acquired major historical aspiration in that of Sass ${ }^{63}$ and Wilson ${ }^{64}$ coming from the fulfillment and

55 Montserrat Huguet Santos, "Historia del Tiempo Presente e Historia de las Relaciones Internacionales", AYER, 42 (2001), 43-69.

56 Jeffrey Kluger, Splendid Solution. Jonas Salk and the Conquest of Polio (New York, 2004)

57 Edward Hooper, The River: A Journey to the Source of HIV and AIDS (Boston, 1999).

58 Debbie Bookchin and Jim Schumacher, The Virus and the Vaccine. Contaminated Vaccine, Deadly Cancers, and Government Neglect (New York, 2004). A review in the scientific literature: Michele Carbone, Paola Rizzo and Harvey I. Pass, "Simian virus 40, poliovaccines and human tumors: a review of recent developments", Oncogene, 15 (1997), 1877-1888.

59 Bernard Seytre and Mary Shaffer, The death of a disease: a history of the eradication of poliomyelitis (New Brunswick, 2005).

60 Montserrat Huguet Santos, "Historia del Tiempo Presente e Historia de las Relaciones Internacionales", $A Y E R, 42$ (2001), 43-69.

61 Kathryn Black, In the Shadow of Polio. A Personal and Social History (Cambridge, Mass., 1996).

62 Marc Shell, Polio and its Aftermath. The Paralysis of Culture (Cambridge, Mass., 2005). Cfr. Rosa Ballester, "Entre la metáfora y la realidad. Discapacidad e identidad en la historia de la poliomielitis", Dynamis, 28 (2008), 419-425.

63 Edmund J. Sass, Polio's Legacy. An Oral History (Lanham, Maryland, 1996).

64 Daniel J. Wilson, Living with Polio. The Epidemic and its Survivors (Chicago, 2005). 
analysis of interviews of affected people ${ }^{65}$. Memory archives as a baseline for an oral history of poliomyelitis have been frequent in United States ${ }^{66}$ and Canadian ${ }^{67}$ historiography, making the experience - including the emotions - one of the most enriching aspects in the history of the illness. Adding to this as much the contributions framed as historical research or as journalistic research have been developed on many occasions by people affected by polio, incorporating new nuances on motivation and subjectivity, memory and history, commitment and activism. $^{68}$

Abundant motives hamper our field of research, the Ibero-American space, we count on autobiographical publications, and moreover there are developing projects, many of whose objectives are articulated in an oral history setting. Dilene Raimundo has led some of these projects ${ }^{69}$ which have generated an archive of testimonials available online. ${ }^{70}$ Her article in this dossier concerning the eradication of poliomyelitis in Brazil tells of one of these testimonies to focus on one of the aspects which usually serve as a corollary in the majority part of the historical accounts on poliomyelitis: post-polio syndrome. The threat of the syndrome gravitates in almost every work centered on the testimonies, establishing the worry for those, who having fought for the consideration of the disability as functional diversity, become ill once more. ${ }^{71}$

65 The testimonies of scientists are usually written memoirs published in collective works: Anne-Marie Moulin, dir., L'aventure de la vaccination (Paris, 1996). Thomas M. Daniel and Frederick C. Robbins, eds, Polio (Rochester, 1997). Stanley A. Plotkin, ed., History of Vaccine Development (New York, 2011).

66 Tony Gould, A Summer Plague. Polio and its Survivors (New Haven, 1995). Julie Silver and Daniel J. Wilson, Polio Voices. An Oral History from the American Polio Epidemics and Worldwide Eradication Efforts (Westport, Connect, 2007).

67 Sally Aitken, Helen D'Orazio and Stewart Valin, eds, Walking Fingers. The Story of Polio and Those Who Lived with It (Georgetown, Ontario, 2004).

68 Serve as examples Aitken, Wilson, Smith, Gould, Shell or Sass.

69 A história da poliomielite e de sua erradicação no Brasil (Programa Estratégico de Pesquisa da Casa de Oswaldo Cruz, Conselho Nacional de Pesquisa de Brasil). A erradicação da poliomielite. Uma história comparada: Brasil e Peru (Edital Universal 01/2002-CNPq).

70 Anna Beatriz de Sá Almeida, Laurinda Rosa Maciel and Dilene Raimundo do Nascimento, Memórias da Poliomielite: acervo de depoimentos orais. 2005. Available from: http://www.bvspolio.coc.fiocruz.br/polio/brasil/acervo/memoriaPoliomielite/index.htm.

71 Heather Green Wooten, The Polio Years in Texas. Battling a Terrifying Unknown (Texas, 2009). Sally Aitken, Helen D'Orazio and Stewart Valin, eds, Walking Fingers. The Story of Polio and Those Who Lived with It (Georgetown, Ontario, 2004). Julie Silver and Daniel J. Wilson, Polio Voices. An Oral History from the American Polio Epidemics and Worldwide Eradication Efforts (Westport, Connect., 2007). Daniel J. Wilson, Living with Polio. The Epidemic and its Survivors (Chicago, 2005), pp. 228-251. Edmund J. Sass, Polio's Legacy. An Oral History (Lanham, Maryland, 1996). Marc Shell, Polio and its Aftermath. The Paralysis of Culture (Cambridge, Mass., 2005), pp. 206-210. Tony Gould, A Summer Plague. Polio and its Survivors (New Haven, 1995). 
If the problems in achieving an authentic eradication of poliomyelitis make it necessary to revisit the past, post-polio syndrome presents one of the major current challenges that should be approached from the point of view of the stories of the people who have lived through the illness and its aftermath, as well as the social significance which the disease has had. Post-polio syndrome exceeds the mere medical and scientific pursuit in that it influences some key elements of the cultural construction of polio in western society: if the person with poliomyelitis sequelae has symbolized the triumph of effort, of will, of the mind over body (and so they have individually assumed this continuous challenge to demonstrate their capacity), the appearance of the syndrome is borne as a failure, a setback and a loss of meaning for the vital project. However, in contrast to that society which is bending over backwards to find a solution to the threat which children suffered and to assist in their rehabilitation, the person with post-polio syndrome confronts obscurity and abandonment in many parts of the world. The necessity to complete this process of eradication, the much announced "endgame", diverts attention from the consequences of polio that linger on, affecting the world free of polio. ${ }^{72}$ Exclusively in this context is it possible to conceive of a syndrome that (in spite of being extensively studied by Dalakas and Halstead and internationally debated since the $80 \mathrm{~s})^{73}$ wasn't included in the International Classification of Diseases until the year $2010,{ }^{74}$ and to all intents and purposes, faced with the problems of low prevalence diseases. ${ }^{75}$ Similarly, it is the people affected who lead social movements in which the role of the expert patient is revalidated, with the help of new virtual social networks, search for and organize the information that many health professionals worldwide are ignorant of.

Poliomyelitis, despite the continually strengthening perception of it as an illness of the past, continues to cause problems for the present public health system and challenges for the immediate future. The answers, more than in any other case, pass necessarily through interdisciplinary areas in which history provides vital keys and can still illuminate multiple aspects open for investigation.

72 Nora Ellen Groce, Lena Morgan Banks and Michael Ashley Stein, "Surviving polio in a post-polio world", Social Science \& Medicine 107 (2014), pp. 171-178.

73 Tony Gould, A Summer Plague. Polio and its Survivors (New Haven, 1995), pp. 209-217.

74 International Statistical Classification of Diseases and Related Health Problems 10th Revision (ICD-10 Version:2010). Available from: http://apps.who.int/classifications/icd10/ browse/2010/en Chapter VI. Diseases of the nervous system (G00-G99). Systemic atrophies primarily affecting the central nervous system (G10-G14). G14 Postpolio Syndrome http://apps.who.int/classifications/icd10/browse/2010/en\#/G10-G14 Polio sequelae are codified as B91.

75 Marc Shell, Polio and its Aftermath. The Paralysis of Culture (Cambridge, Mass., 2005). 


\section{References}

Sally Aitken, Helen D'Orazio and Stewart Valin, eds, Walking Fingers. The Story of Polio and Those Who Lived with It. (Georgetown, 2004).

Álvarez, Adriana, "Parálisis y acción': el caso argentino frente a los brotes de poliomielitis de mediados del siglo XX," pp. 259-261 in María Isabel Porras et al., eds, Transmisión del conocimiento médico e internacionalización de las prácticas sanitarias: una reflexión histórica. (Ciudad Real, 2011).

Álvarez, Adriana, María Isabel Porras Gallo and María José Báguena, coords., "Perspectivas internacionales de la salud en la América Latina. Programas métodos y experiencias locales en la lucha contra la poliomielitis (19301960)," pp. 233-261 in María Isabel Porras et al., eds, Transmisión del conocimiento médico e internacionalización de las prácticas sanitarias: una reflexión histórica. (Ciudad Real, 2011).

Julio Aróstegui, La historia vivida. Sobre la historia del presente. (Madrid, 2004).

Ballester, Rosa, "Entre la metáfora y la realidad. Discapacidad e identidad en la historia de la poliomielitis," Dynamis 28 (2008), 419-425.

Rosa Ballester and María Isabel Porras, eds, "Políticas, respuestas sociales y movimientos asociativos frente a la poliomielitis: la experiencia europea," Dynamis 32(2) (2012), 273-414.

Bedarida, François, "Definición, método y práctica de la Historia del Tiempo Presente," Cuadernos de Historia Contemporánea 20 (1998), 19-27.

Beldarraín, Enrique, "Poliomyelitis and Its Elimination" In Cuba: An Historical Overview," MEDICC Review 15(2) (2013), 30-36.

Berridge, Virginia, "History in Public Health: a New Development for History?," Hygiea Internationalis 1(1) (1999), 23-35.

Kathryn Black, In the Shadow of Polio. A Personal and Social History. (Cambridge, Mass., 1996).

Debbie Bookchin and Jim Schumacher, The Virus and the Vaccine. Contaminated Vaccine, Deadly Cancers, and Government Neglect. (New York, 2004).

Brown, Theodore M., Marcos Cueto and Elizabeth Fee, "The World Health Organization and the Transition From 'International' to 'Global' Public Health," American Journal of Public Health 96(1) (2006), 62-72.

Carbone, Michele, Paola Rizzo and Harvey I. Pass, "Simian virus 40, poliovaccines and human tumors: a review of recent developments," Oncogene 15 (1997), $1877-1888$.

Carrillo, Ana María "Vacunación y educación higiénica en la campaña contra la poliomielitis en México," pp. 247-251 in María Isabel Porras et al., eds, 
Transmisión del conocimiento médico e internacionalización de las prácticas sanitarias: una reflexión histórica. (Ciudad Real, 2011).

Cello, J., A.V. Paul, E. Wimmer, "Chemical Synthesis of Poliovirus cDNA: Generation of Infectious Virus in the Absence of Natural Template," Science 297(5583) (2002), 1016-1018.

Cohen, Jeffrey I. "Enterovirus y reovirus," I:1208-1213 in A. Fauci et al., eds, Harrison Principios de Medicina Interna. Madrid, 2012, 17 ed.

Cuesta Bustillo, Josefina, "La historia del tiempo presente: estado de la cuestión," Studia Historica. Historia Contemporánea 1 (1983), 227-241.

Marcos Cueto, El valor de la salud. Una historia de la OPS. (Washington, 2004).

Cueto, Marcos, "Los orígenes de la Atención Primaria de Salud y la Atención Primaria Selectiva de Salud," pp. 27-58 in Marcos Cueto and Víctor Zamora, eds, Historia, Saludy Globalización. (Lima, 2006).

Thomas M. Daniel and Frederick C. Robbins, eds, Polio. (Rochester, 1997).

Dowdle, Walter R. "The principles of disease elimination and eradication," Bulletin of the World Health Organization 76: Suppl. 2 (1998), 22-25.

European Centre for Disease Prevention and Control, "Suspected outbreak of poliomyelitis in Syria: Risk of importation and spread of poliovirus in the EU," Rapid Risk Assessment. 23 October 2013. Cited 2014 Jan 17. Available from:

http://www.ecdc.europa.eu/en/publications/Publications/RRA\%20poliomyelit is\%20Syria\%2021\%2010\%202013.pdf.

European Centre for Disease Prevention and Control, "Expert consultation on scientific evidence linked to polio virus in Israel and Syria," Meeting Report. 5 November 2013. Cited 2014 Jan 17. Available from: http://www.ecdc.europa.eu/en/publications/Publications/Expert\%20consultati on\%20mtg\%20report\%20-\%20polio\%20Israel\%20Syria\%20-\%20final.pdf.

García-Sánchez, José Elías, Enrique García-Sánchez, Enrique García-Merino and María José Fresnadillo-Martínez, "La polio, el largo caminho hacia el final de la partida," Enfermedades Infecciosas y Microbiología Clínica. In print. Cited 2015 Mar 17. Available from http://dx.doi.org/10.106/ j.eimc.2014.10.005

González, Magdalena "La teorización de Julio Aróstegui sobre la historia del tiempo presente como historia vivida," Hispania Nova 13 (2015), 126-133.

Tony Gould, A Summer Plague. Polio and its Survivors. (New Haven, 1995).

Groce, Nora Ellen, Lena Morgan Banks and Michael Ashley Stein, "Surviving polio in a post-polio world," Social Science \& Medicine 107 (2014), 171-178.

Hampton, Lee "Albert Sabin and the Coalition to Eliminate Polio from the Americas," American Journal of Public Health 99(1) (2009), 34-44.

Heymann, D. and Q. Ahmed, "The polio eradication end game: what it means for Europe," Euro Surveillance, 19(7) (2014), 1-7. Cited 2014 Mar 5. Available 
from: http://www.eurosurveillance.org/images/dynamic/EE/ V19N07/art20702.pdf

Edward Hooper, The River: A Journey to the Source of HIV and AIDS. Boston, 1999. Huguet Santos, Montserrat, "Historia del Tiempo Presente e Historia de las Relaciones Internacionales," AYER 42 (2001), 43-69.

Jovell, J., "El paciente del siglo XXI," Anales del Sistema Sanitario de Navarra 29: supl. 3 (2006), 85-90.

Kaliner, E., J. Moran-Gilad, I. Grotto, E. Somekh, E. Kopel, M. Gdalevich, E. Shimron, Y. Amikam, A. Leenthal, B. Lev and R. Gamzu, "Silent reintroduction of wild-type poliovirus to Israel, 2013 - Risk communication challenges in an argumentative atmosphere," Euro Surveillance, 19(7) (2014), 1-7. Cited 2014 Mar 5. Available from: http://www.eurosurveillance.org/ images/dynamic/EE/V19N07/art20703.pdf

Kenneth F. Kiple, ed., The Cambridge World History of Human Disease Past and Present. (Cambridge, 1993).

Kenneth F. Kiple, ed., The Cambridge Historical Dictionary of Disease. Cambridge, 2003.

Jeffrey Kluger, Splendid Solution. Jonas Salk and the Conquest of Polio. New York, 2004.

George C. Kohn, Encyclopedia of Plague and Pestilence: From Ancient Times to the Present. (New York, 1995).

Koprowski, Hilary and Stanley Plotkin,"Histoire alternative du vaccin oral," pp. 299-310 in Anne-Marie Moulin, dir., L'aventure de la vaccination. (Paris, 1996).

Koprowski, Hilary and Stanley Plotkin, "History of Koprowski Vaccine Against Poliomyelitis," pp. 155-166 in Stanley A. Plotkin, ed., History of Vaccine Development. (New York, 2011).

Laval, Enrique, "Anotaciones para la historia de la poliomielitis en Chile," Revista Chilena de Infectología 24(3) (2007), 247-250.

Lindner, Ulrike and Stuart S. Blume, "Vaccine Innovation and Adoption: Polio Vaccines in the UK, the Netherlands and West Germany, 1955-1965," Medical History, 50 (2006), 425-446.

Malavassi Aguilar, Ana Paulina, "Representaciones sobre la epidemia de poliomielitis en el periódico La Nación. Costa Rica, 1954," pp. 237-239 in María Isabel Porras et al., eds, Transmisión del conocimiento médico e internacionalización de las prácticas sanitarias: una reflexión histórica. (Ciudad Real, 2011).

Martínez-Pérez, José, "Presentación: la poliomyelitis como modelo para el studio de la enfermedad en perspectiva histórica," Asclepio 61(1) (2009), 7-21. 
José Martínez-Pérez, coord., "La poliomielitis y sus contextos: experiencias colectivas e individuales ante la enfermedad en el siglo XX," Asclepio 61(1) (2009), 7-192.

Más Lago, P., "Eradication of poliomyelitis in Cuba: a historical perspective," Bulletin of the World Health Organization 77(8) (1999), 681-687.

Melnick, Joseph L., "The Picornaviruses," pp. 147-188 in F. Fenner and A. Gibbs, eds, Portraits of Viruses. A History of Virology. (Basel, 1988).

Melnick, Joseph and Stanley Plotkin, "Oral Polio Vaccine and the Results of Its Use," pp. 167-177 in Stanley A. Plotkin, ed., History of Vaccine Development. (New York, 2011).

Modin, J.F., "Poliovirus," pp. 2305-2315 in G.L. Mandell, J.E. Bennett and R. Dolin, Enfermedades Infecciosas. Principios y Práctica. (Madrid, 2002, 5 ed.).

Mosquera Gordillo, Miguel Armando, Natalia Barón Cano and Rosa Ballester Añón, "El camino hacia la erradicación de la poliomielitis a través de la Organización Panamericana de la Salud," Revista Panamericana de Salud Pública, 36(3) (2014), 185-192.

Anne-Marie Moulin, dir., L'aventure de la vaccination. Paris, 1996.

Dilene Raimundo do Nascimento, org., A história da poliomielite. (Rio de Janeiro, 2010).

Nascimento, Dilene Raimundo do, Marcos Cueto, Eduardo Ponce Maranhão and Deepak Sobti, "A erradicação da poliomielite na América Latina: comparando Brasil e Peru," pp. 161-176 in Dilene Raimundo de Nascimento, org., $A$ história da poliomielite. (Rio de Janeiro, 2010).

Nathanson, Neal and J.R. Martin, "The epidemiology of poliomyelitis: enigmas surrounding its appearance, epidemicity, and disappearance," American Journal of Epidemiology 110(6) (1979), 672-692.

Nathanson, Neal and Olen M. Kew, "From Emergence to Eradication: The Epidemiology of Poliomyelitis Deconstructed," American Journal of Epidemiology 172 (2010), 1213-1229.

Paul A. Offit, The Cutter Incident. How America's First Polio Vaccine Led to the Growing Vaccine Crisis. (New Haven, 2005).

Michael B.A. Oldstone, Viruses, Plagues, and History. Past, Present, and Future. (New York, 2010).

David M. Oshinsky, Polio: An American Story. (New York, 2005).

John R. Paul, A History of Poliomyelitis. (New Haven, 1971).

Perdiguero, E., J. Bernabeu, R. Huertas, E. Rodríguez-Ocaña, "History of health, a valuable tool in public health," Journal of Epidemiology and Community Health 55 (2001), 667-673.

Pinto, Sandrine Martins, Inês Guerra, Juan Antonio Rodríguez-Sánchez, João Rui Pita y Ana Leonor Pereira, "De las campañas de vacunación al calendario vacunal: el Programa Nacional de Vacinação portugués y las Campañas 
Nacionales de Vacunación Antipoliomielítica en España (1963-1976),” pp. 203-209 in Ricardo Campos Marín, Ángel González de Pablo, María Isabel Porras Gallo y Luis Montiel, eds, Medicina y poder politico. (Madrid, 2014).

Pita, João Rui and Juan Antonio Rodríguez-Sánchez, "Actitudes ante la polio en España y Portugal: estudio comparativo," pp. 331-334 in Teresa Ortiz et al., eds, La experiencia de enfermar en perspectiva histórica. (Granada, 2008).

Stanley A. Plotkin, ed., History of Vaccine Development. (New York, 2011).

Porter, Roy, "The Patient's View: Doing Medical History from Below", Theory and Society 14(2 (1985), 175-198.

María Isabel Porras Gallo, Mariano Ayarzagüena Sanz, Jaime de las Heras Salord y María José Báguena Cervellera, coords., El drama de la polio: un problema social y familiar en la España franquista. (Madrid, 2013).

Quevedo, Emilio, Mario Hernández, Claudia Cortés and Juan Carlos Eslava, "Un modelo para armar: Una propuesta metodológica para abordar el estudio comparativo de la historia de la salud pública, de las profesiones de la salud y de sus relaciones de doble vía con la sociedad," Revista de Ciencias de la Salud 11(3) (2013), 295-321.

Racaniello, V.R., "One hundred years of poliovirus pathogenesis," Virology, 344 (2006), 9-16.

Ramacciotti, Karina Inés, "Las sombras de la política sanitaria durante el peronismo: los brotes epidémicos en Buenos Aires", Asclepio 58(2) (2006), 115138.

Rodríguez-Sánchez, Juan Antonio, "La persona enferma como experta: los cambios sociosanitarios promovidos por el asociacionismo polio-postpolio en España", Estudos do Século XX 12 (2012), 104-122.

Rodríguez-Sánchez, Juan Antonio, "La historia de la poliomielitis, historia del presente", Temperamentvm 16 (2012). Cited 2013 Jan 30. Available from: http://www.index-f.com/temperamentum/tn16/t2712.php

Rodríguez-Sánchez, Juan Antonio, Rosa Ballester Añón and Inês Guerra Santos, "El movimento asociativo: una perspectiva internacional, nacional y de los casos de Madrid, Valencia y Castilla - La Mancha," pp. 233-257 in María Isabel Porras Gallo, Mariano Ayarzagüena Sanz, Jaime de las Heras Salord y María José Báguena Cervellera, coords., El drama de la polio: un problema social y familiar en la España franquista. (Madrid, 2013).

Naomi Rogers, Dirt and Disease: Polio before FDR. (New Brunswick, 1992).

Charles Rosenberg, Explaining Epidemics and Other Studies in the History of Medicine. (New York, 1992).

Sabin, Albert B., "Oral poliovirus vaccine: history of its development and use and current challenge to eliminate poliomyelitis from the world," Journal of Infectious Diseases 151(3), 1985, 420-436.

Edmund J. Sass, Polio's Legacy. An Oral History. (Lanham, Maryland, 1996). 
Bernard Seytre and Mary Shaffer, The death of a disease: a history of the eradication of poliomielitis. (New Brunswick, 2005).

Marc Shell, Polio and its Aftermath. The Paralysis of Culture. (Cambridge, Mass., 2005).

Siegler, M., "La relación médico-paciente en la era de la medicina de gestión," pp. 44-64 in Limitación de prestaciones sanitarias. (Madrid, 1997).

Julie Silver and Daniel J. Wilson, Polio Voices. An Oral History from the American Polio Epidemics and Worldwide Eradication Efforts. (Westport, Connect, 2007).

Mathew Smallman-Raynor and Andrew D. Cliff, Poliomyelitis: Emergence to Eradication. (Oxford, 2006).

Sobti, Deepak, Marcos Cueto and Y. He, "A public health achievement under adversity: the eradication of poliomyelitis from Peru, 1991," American Journal of Public Health, 2014, 104(12), 2298-2305.

Sundin, Jan, "Why Hygiea Internationalis?," Hygiea Internationalis 1(1) (1999), 5-7. Testa, Daniela, "Poliomielitis: la 'herencia maldita' y la esperanza de la rehabilitación. La epidemia de 1956 en la ciudad de Buenos Aires," Instersticios 5(2) (2011), 309-323.

Testa, Daniela, "La lucha contra la poliomielitis: una alianza médico-social, Buenos Aires, 1943," Salud Colectiva 8(3) (2012), 299-314.

Testa, Daniela, "Curing by doing: la poliomielitis y el surgimiento de la terapia ocupacional en Argentina, 1956-1959," História, Ciências, Saúde-Manguinhos 20(4) (2013), 1571-1584.

Testa, Daniela, "El síndrome pos-polio y sus anudamientos en el pasado," Instersticios 8(1) (2014), 233-248.

Vargha, Dora, "Between East and West: Polio Vaccination across the Iron Curtain in Cold War Hungary," Bulletin of the History of Medicine 88(2) (2014), 319343.

Daniel J. Wilson, Living with Polio. The Epidemic and its Survivors. (Chicago, 2005).

Heather Green Wooten, The Polio Years in Texas. Battling a Terrifying Unknown. Texas, 2009.

World Health Organization, Polio Eradication \& Endgame Strategic Plan 20132018. Geneva, 2013. Cited 2014 Mar 23. Available from http://www.polioeradication.org/Portals/0/Document/Resources/StrategyWor k/PEESP_EN_US.pdf 


\section{Acknowledgements}

This work has been carried out as part of Project HAR2012-39655-C04-03 of the Spanish Ministry of Innovation, Economy and Competitiveness (MINECO) and SA359A12-1 and SA251U14 (Junta de Castilla y León). 